\title{
Molecular evidence for the presence of Leptospira borgpetersenii in synanthropic rodents in the Nautla region, Veracruz, México
}

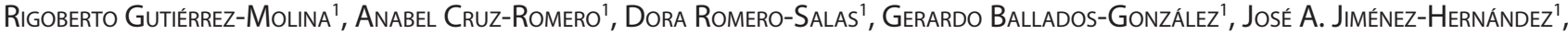 \\ Nelly Ibarra-Priego ${ }^{1}$, Ricardo Serna-Lagunes ${ }^{2}$ and Sokani Sánchez-Montes ${ }^{3 *}$ \\ ${ }^{1}$ Facultad de Medicina Veterinaria y Zootecnia, región Veracruz. Universidad Veracruzana. Miguel Ángel de Quevedo s/n, CP. 91710. \\ Veracruz, México. Email:iori luna25@hotmail.com (RGM), anabcruz@uv.mx (ACR),dromero@uv.mx (DRS), balladosgerardo506@ \\ hotmail.com (GGBG), mvzjimenez.850114@gmail.com (JAJH), nellydeljesus@yahoo.com.mx (NIP). \\ ${ }^{2}$ Facultad de Ciencias Biológicas y Agropecuarias, región Orizaba-Córdoba. Universidad Veracruzana. Carretera Peñuelas Amatlán \\ Kilómetro 177, CP. 94500. Veracruz, México. Email: rserna@uv.mx (RSL). \\ ${ }^{3}$ Centro de Medicina Tropical, Unidad de Medicina Experimental, Facultad de Medicina. Universidad Nacional Autónoma de \\ México. Dr. Balmis 148, CP. 06726, Ciudad de México. México. Email: sok10108@gmail.com (SSM). \\ *Corresponding author
}

The genus Leptospira encompasses ten species of spirochetes capable of infecting mammals, particularly rodents. In México, studies focused on the detection of Leptospira sp. in rodents are scarce, all of them restricted to three states of the Gulf of México. For this reason, this work aimed to identify the diversity of Leptospira species associated with synanthropic rodents in Veracruz, a state where leptospirosis is endemic. Rodents were sampled with Sherman traps placed in 10 Production Units across the Nautla region. Animals were euthanized and their kidneys removed. Subsequently, a 474-bp segment of the outer membrane protein LipL32, present in all pathogenic species, was amplified and sequenced. Sequences were compared vs. reference using the BLAST algorithm: a phylogenetic reconstruction was carried out using the Maximum Likelihood method. In addition, the prevalence of infection in each Production Unit was estimated. Twenty eight rodents of a single species (Mus musculus) were caught. Leptospira DNA was detected in 17 samples $\left(62.9 \%, \mathrm{Cl}_{95 \%} 42.3\right.$ to 80.6$)$ from seven localities in the Nautla region. The sequences recovered exhibited $99-100 \%$ identity to each other and $99 \%$ identity with Leptospira borgspetersenii sequences deposited in GenBank. This study confirms the presence of L. borgspetersenii in rodents, particularly in M. musculus, in México. This study increases the inventory of pathogenic leptospires for the state of Veracruz to three species.

El género Leptospira engloba 10 especies de espiroquetas capaces de infectar mamíferos, particularmente roedores. En México se han realizado escasos estudios para la detección de Leptospira sp. en roedores, todos ellos restringidos a tres estados del Golfo de México. Por tal motivo el objetivo del presente trabajo fue identificar la diversidad de leptospiras en roedores sinantrópicas de Veracruz, un estado endémico de leptospirosis. Para la colecta de roedores, se colocaron trampas tipo Sherman en 10 unidades de producción de la región Nautla. Los animales se sacrificaron y se obtuvieron los riñones. Posteriormente se amplificó y secuenció un segmento de 474 pb de la proteína exterior de membrana LipL32 presente en las leptospiras patógenas. Posteriormente se compararon las secuencias con las de referencia mediante el uso del algoritmo BLAST y se realizó una reconstrucción filogenética mediante el método de Máxima Verosimilitud. Adicionalmente se obtuvieron las prevalencias de la infección por unidad de producción. Se colectaron 28 roedores de una única especie (Mus musculus). Se detectó la presencia de ADN de Leptospira en 17 muestras (62.9\%; IC ${ }_{95} 42.3$ a 80.6) procedentes de siete localidades de la región Nautla. Las secuencias recuperadas exhibieron una similitud del 99-100 \% entre si y una identidad del $99 \%$ con secuencias de referencia de Leptospira borgspetersenii depositadas en GenBank. Este estudio confirma la presencia de L. borgspetersenii en roedores y en particular con M. musculus en México. Este estudio incrementa a tres especies el inventario de leptospiras patógenas para el estado de Veracruz.

Keywords: México; pathogens; small mammals; spirochetes.

C 2019 Asociación Mexicana de Mastozoología, www.mastozoologiamexicana.org

\section{Introduction}

The genus Leptospira encompasses a set of thin bacteria with hook-shaped tips that inhabit lentic habitats worldwide, particularly wetlands (Levett 2015). Previously, the existence of two species was recorded: a saprophytic species thriving in aquatic environments ( $L$. biflexa) and a pathogenic one causing a zoonosis called leptospirosis ( $L$. interrogans; Levett 2015). Today, 35 species are acknowledged, classified into three groups based on their ability to infect vertebrate hosts: non-pathogenic (e. g., L. biflexa, I. idonoii, and L. meyeri), facultative pathogenic (e. g., L. broomii, L. fainei, and L. wolffii) and pathogenic (e. g., L. alexanderi, L. borgpetersenii, L. interrogans, and L. kirschneri; Bourhy et al. 2014; Thibeaux et al. 2018).
Ten pathogenic species are currently known, which have been reported in more than 160 species of wild and domestic mammals around the world (Ballados-González et al. 2018). In particular, rodents play a role as reservoirs; many murine species exhibit chronic infections and continually release bacteria in urine, a phenomenon called leptospiruria. Members of the family Muridae serve as the main reservoirs of Leptospira sp., and are deemed responsible for spreading the infection to livestock, pets, and humans (da Silva et al. 2010; Colombo et al. 2018).

In México, few studies have been conducted to detect Leptospira sp. in rodents, mostly in the states of Tamaulipas, Campeche, and Yucatán (Méndez et al. 2013; EspinosaMartínez et al. 2015; Torres-Castro et al. 2016; Panti-May et 
al. 2017; Torres-Castro et al. 2018). These studies provide molecular evidence of the presence of $L$. interrogans and $L$. kirschneri in various species of rodents of the families Cricetidae, Heteromyidae, and Muridae. However, there are other states of México where human and bovine leptospirosis is a major public health issue. Specifically, the state of Veracruz records an incidence of human leptospirosis of five cases per 100,000 inhabitants, and seroprevalence in livestock ranging between $60 \%$ and $80 \%$ (Moles-Cervantes et al. 2002; Álvarez et al. 2005; Sánchez-Montes et al. 2015; Zárate-Martínez et al. 2015). However, there is no evidence on the Leptospira species maintained in rodent populations in the region. The aim of the present work was to determine the presence and diversity of Leptospira sp. in synanthropic rodents in the Nautla region, Veracruz, México.

\section{Materials and Methods}

This study was conducted in well-defined and delimited areas that have facilities, machinery, and equipment to carry out livestock activities, named Livestock Production Units (LPU), in the municipalities of San Rafael, Nautla, Martínez de la Torre, Vega de Alatorre, and Misantla, in the Nautla region, Veracruz (Figure 1). This region is located in the center-northern portion of the State of Veracruz. It is bordered by the Totonac region to the north, the Capital and Mountain regions to the south, the Gulf of México to the east, and the state of Puebla to the west. This region covers an area of $3,329 \mathrm{~km}^{2}$, with $86.1 \%$ dedicated to farming activities; in turn, $43.2 \%$ is covered by pastures for cattle raising.

Rodents were sampled from November 2016 to May 2017 on Production Units across the Nautla region, Veracruz. In each Production Unit, Sherman traps were placed $(8 \times 9 \times 23 \mathrm{~cm})$, using an oat-vanilla mixture as bait attractant. Forty traps were placed per Production Unit, strategically distributed in areas with high probability of occurrence of rodents such as warehouses, farmyards, or inside households. Traps were placed in the afternoon and reviewed the next morning (before $7 \mathrm{am}$ ) during two trapping nights

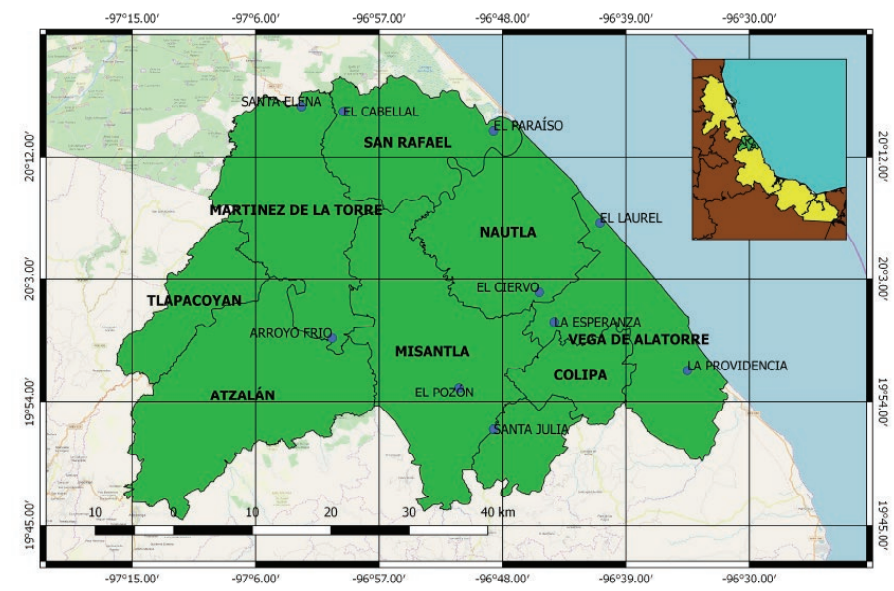

Figure 1. Map of the location of the Production Units sampled in the Nautla region, Veracruz, Mexico. The municipalities that make up the Nautla region are highlighted in green. The localities sampled are marked with blue circles. in each locality. The rodents captured were removed from traps, identified, and processed for kidney sample collection following biosafety standards, under collection license FAUT-0250 granted by the Secretariat of Environment and Natural Resources (Semarnat). Animals were euthanized according to the protocol established by NOM-033-SAG/ ZOO-2014 using ketamine (Wildlife Pharmaceutics México SA de CV 04930, México) as anesthetic agent, followed by cervical dislocation. Each rodent was placed in supine position and the absence of reflexes (corneal and podal) was confirmed before dissection to remove the kidneys. Kidney samples were placed in containers with $70 \%$ alcohol and kept at $4^{\circ} \mathrm{C}$ until processing.

DNA extraction was carried out in each sample separately, using $500 \mu \mathrm{l}$ of a $10 \%$ solution of the resin Chelex 100 added with $20 \mu \mathrm{l}$ of proteinase $\mathrm{K}$; then samples were incubated at $56{ }^{\circ} \mathrm{C}$ for two hours (Ballados-González et al. 2018). Afterward, samples were centrifuged at $15,000 \mathrm{rpm}$ for 15 minutes; the supernatant was transferred to new tubes and stored at $-20^{\circ} \mathrm{C}$.

Once the sample was obtained, a 474-bp segment of the outer membrane protein LipL32, present in the genome of the pathogenic Leptospira species, was amplified using the oligonucleotides (ATCTCCGTTGCACTCTTTGC) and LipL32 reverse (GTCCGCCTACACACCCTTTAC; Vital-Brazil et al. 2010). The reaction mixture consisted of $12.5 \mu \mathrm{l}$ of a $2 X$ solution of $\mathrm{GoTaq}^{\circledR}$ Green Master Mix (Promega Corporation, Madison, WI, USA), $1 \mu$ l of each oligonucleotide ( $2 \mu \mathrm{M}$ each), $6.5 \mu \mathrm{L}$ of DNase-free water, and $4 \mu \mathrm{l}$ of DNA (200-300 ng) to make a final volume of $25 \mu \mathrm{L}$ (Espinosa-Martínez et al. 2015; Ballados-González et al. 2018). Amplicons were visualized on agarose gels using $2 \%$ TAE buffer at $85 \mathrm{~V}$ for $45 \mathrm{~min}$.

Positive PCR products were sent to the Biology Institute at Universidad Nacional Autónoma de México for sequencing. The resulting sequences were compared with those deposited in GenBank to determine the similarity between them using the BLAST tool.

Global alignments were carried out between the sequences produced in this study and some representative pathogenic leptospires deposited in GenBank, with the algorithm Clustal W using the software MEGA 6.0 (Tamura et al. 2013). The Tamura's three-parameter model of nucleotide substitution (T92) was selected based on the lowest Bayesian Information Criterion (BIC) score $(2,497,948)$. In addition, a phylogenetic reconstruction was conducted using the maximum likelihood (ML) approach; the support of the topology was validated with 10,000 bootstrap replicates, also in MEGA 6.0.

\section{Results}

A total of 28 specimens of Mus musculus were collected. None of the collected animals showed signs of disease at the time of collection, nor gross evidence of renal impairment. Leptospira DNA was detected in 17 of the 28 samples analyzed (62.9\%; $\mathrm{Cl}_{95 \%} 42.3$ to 80.59 ). Positive samples 
were obtained from animals collected in the localities of La Providencia, La Esperanza, Santa Julia, El Pozón, El Laurel, El Cabellal, and Tres Marías (Table 1).

The localities with the highest number of positive mice were Santa Julia (municipality of Misantla), and El Cabellal (municipality of San Rafael), with four positive specimens each (Table 1). Of the 17 positive PCR products, 12 sequences of 460 to 470 base pairs were recovered. The recovered sequences exhibited $99 \%$ identity between them (457/460 bp), and $99 \%$ identity (458/460 bp) with sequences of $L$. borgpetersenii deposited in GenBank. In addition, the phylogenetic analysis encompassed the sequences observed in this study along with the reference sequence of $L$. borgpetersenii in a monophyletic group with a support value of 100 (Figure 2). The sequences generated in this study were deposited in GenBank with access numbers MK568973-MK568984.

\section{Discussion}

This work is the first approximation to the study of Leptospira in rodents in the northern part of the state of Veracruz. Besides, it represents the first molecular confirmation of the presence of $L$. borgspetersenii in rodents, particularly in Mus musculus, in México (Espinosa-Martínez et al. 2015; TorresCastro et al. 2016, 2018; Panti-May et al. 2017). The reference serovar of $L$. borgspetersenii isolated from $M$. musculus is Ballum, which was detected in the past century in Europe (Yager et al. 1953). Since then, multiple serological and molecular studies have shown that this serovar is widely distributed across M. musculus populations worldwide (da Silva et al. 2010; Matsui et al. 2015; Colombo et al. 2018). In México, studies conducted in the state of Durango have reported titers of antibodies to the L. borgspetersenii Ballum serovar in domestic animals such as pigs and donkeys (Alvarado-Esquivel et al. 2018; Cruz-Romero et al. 2018). Thus, it is reasonable to assume that domestic animals can be exposed to bacteria through rodents and food or water sources contaminated with rodent urine in farmyards or livestock handling and processing areas.

Table 1. Location of the Production Units sampled in the Nautla region, Veracruz, Mexico. $\mathrm{RC}=$ Rodents collected; $\mathrm{PR}=$ Positive rodents; $\%=$ Prevalence

\begin{tabular}{llllllr}
\hline \multicolumn{1}{c}{ Locality } & \multicolumn{1}{c}{ Municipality } & Latitude & Longitude & RC & PR & $\%$ \\
\hline La Providencia & Vega de Alatorre & $19^{\circ} 56^{\prime} 0.47^{\prime \prime}$ & $-96^{\circ} 32^{\prime} 59.02^{\prime \prime}$ & 2 & 1 & 50 \\
El Ciervo & Vega de Alatorre & $20^{\circ} 02^{\prime} 00.31^{\prime \prime}$ & $-96^{\circ} 45^{\prime} 18.97^{\prime \prime}$ & 1 & 0 & 0 \\
La Esperanza & Vega de Alatorre & $19^{\circ} 59^{\prime} 53.26^{\prime \prime}$ & $-96^{\circ} 44^{\prime} 13.48^{\prime \prime}$ & 2 & 1 & 50 \\
Santa Julia & Misantla & $19^{\circ} 52^{\prime} 00.26^{\prime \prime}$ & $-96^{\circ} 48^{\prime} 38.30^{\prime \prime}$ & 5 & 4 & 80 \\
El Pozón & Misantla & $19^{\circ} 55^{\prime} 03.14^{\prime \prime}$ & $-96^{\circ} 51^{\prime} 09.71^{\prime \prime}$ & 5 & 2 & 40 \\
El Laurel & Vega de Alatorre & $20^{\circ} 07^{\prime} 04.62^{\prime \prime}$ & $-96^{\circ} 40^{\prime} 53.18^{\prime \prime}$ & 1 & 1 & 100 \\
El Paraíso & San Rafael & $20^{\circ} 13^{\prime} 51.00^{\prime \prime}$ & $-96^{\circ} 48^{\prime} 39.09^{\prime \prime}$ & 3 & 0 & 0 \\
El Cabellal & San Rafael & $20^{\circ} 15^{\prime} 15.24^{\prime \prime}$ & $-96^{\circ} 59^{\prime} 36.23^{\prime \prime}$ & 4 & 4 & 100 \\
Santa Elena & Martínez de la Torre & $20^{\circ} 13^{\prime} 55.49^{\prime \prime}$ & $-97^{\circ} 01^{\prime} 23.89^{\prime \prime}$ & 4 & 3 & 75 \\
Arroyo Frio & Martínez de la Torre & $19^{\circ} 58^{\prime} 43.10^{\prime \prime}$ & $-97^{\circ} 00^{\prime} 25.23^{\prime \prime}$ & 1 & 1 & 100 \\
\hline Total & & & & 28 & 17 & 60.7 \\
\hline
\end{tabular}

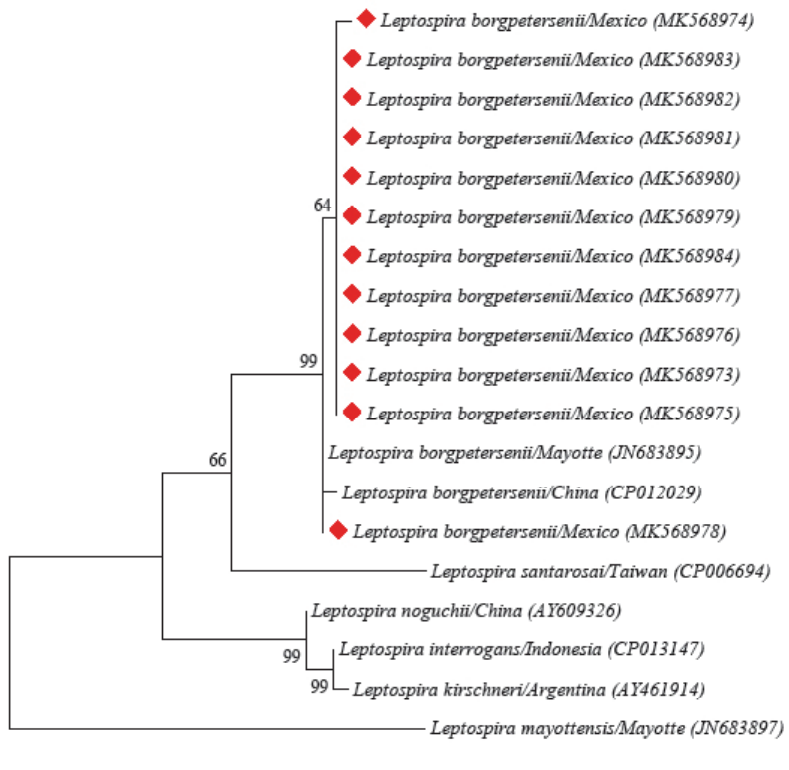

Figure 2. Phylogenetic tree of some pathogenic Leptospira species, obtained using the maximum likelihood (ML) approach and the Tamura's three-parameter model (TN93). The sequences recovered from rodents (Mus musculus) sampled in this study are marked with red diamonds.

The presence of two additional species of pathogenic leptospires (L. weilli and L. noguchii) has been confirmed in the state of Veracruz, both in kidney tissue samples of the hematophagous bat Desmodus rotundus and the frugivorous bat Artibeus jamaicensis (Ballados-González et al. 2018). Therefore, this study increases the inventory of pathogenic leptospires of Veracruz to three species. These findings in rodents suggest the existence of multiple transmission cycles in both wild and anthropic environments, which should be evaluated carefully.

\section{Literature cited}

Alvarado-Esquivel, C., A. Cruz-Romero, D. Romero-Salas, A. Alvarado-Félux, M. Aguilar-Domínguez, J. L. Ochoa-Valencia, D. Alvarado-Esquivel, J. Hernandez-Tinoco, J. A. Zamarripa-Barboza, AND L. F. SÁnChez-Anguiano. 2018. Apparently high Leptospira antibody seropositivity in donkeys for slaughter in three municipalities in Durango, México. Journal of Veterinary Diagnostic Investigation 30:929-932.

Alvarez, M. A., L. P. Moles-Cervantes, D. G. Rosas, C. N. Vasquez, AND F. S. GARCíA. 2005. Retrospective seroprevalence study of bovine leptospirosis in México considering the ecological regions. Revista Cubana de Medicina Tropical 57:28-31.

Ballados-González, G. G., S. Sánchez-Montes, D. Romero-Salas, P. Colunga-Salas, R. Gutiérrez-Molina, L. León-Paniagua, I. Becker, M. L. Méndez-Ojeda, C. Barrientos-Salcedo, R. Serna-Lagunes, and A. CRuz-Romero. 2018. Detection of pathogenic Leptospira species associated with phyllostomid bats (Mammalia: Chiroptera) from Veracruz, México. Transboundary and Emerging Diseases 65:773-781.

Bourhy, P., L. Collet, S. Brisse, and M. Picardeau. 2014. Leptospira mayottensis sp. nov., a pathogenic species of genus Leptospira isolated from humans. International Journal of Systematic and Evolutionary Microbiology 64:4061-4067. 
Colombo, V. C., I. Gamietea, S. G. Loffler, B. F. Brihuega, and P. M. BELDOMENICO. 2018. New hostspecies for Leptospiraborgpetersenii and Leptospira interrogans serovar Copenhageni. Veterinary Microbiology 215:90-92.

Cruz-Romero, A., C. Alvarado-Esquivel, D. Romero-Salas, A. O. Alvarado-Félix, S. Sánchez-Montes, J. Hernández-Tinoco, and L. F. SÁnchez-Anguiano. 2018. Seroepidemiology of Leptospira infection in backyard pigs in Durango State, México. European Journal of Microbiology and Immunology 8:87-90. da Silva, E. F., S. R. Félix, G. M. Cerqueira, M. Q. Fagundes, A. C. Neto, A. A. Grassmann, M. G. Amaral, T. Gallina, and O. A. Dellagostin. 2010. Preliminary characterization of Mus musculus-derived pathogenic strains of Leptospira borgpetersenii serogroup Ballum in a hamster model. American Journal of Tropical Medicine and Hygiene 83:336-337.

Espinosa-Martínez, D. V., D. S. Sánchez-Montes, L. León-Paniagua, C. A. Ríos-Muñoz, M. Berzunza-Cruz, ANd I. BeCKer. 2015. New wildlife hosts of Leptospira interrogans in Campeche, México. Revista do Instituto de Medicina Tropical de São Paulo 57:181-183.

LeVett, P. N. 2015. Systematics of leptospiraceae. Current Top Microbiology and Immunology 387:11-20.

Matsui, M., L. Roche, M. E. Soupé-Gilbert, M. Roudier, V. Moniquet, AND C. Goarant. 2015. Experimental hamster infection with a strain of Leptospira borgpetersenii Ballum isolated from a reservoir mouse in New Caledonia. American Journal of Tropical Medicine and Hygiene 92:982-985.

Méndez, C., L. Benavides, A. Esquivel, A. Aldama, J.Torres, D. Gavaldón, P. Meléndez, and L. Moles. 2013. Pesquisa serológica de Leptospira en roedores silvestres, bovinos, equinos y caninos en el noreste de México. Revista de Salud Animal 35:25-32.

Moles-Cervantes, L. P., M. A. Cisneros-Puebla, D. G. Rosas, N. R. Serranía, and J. I. Torres-Barranca. 2002. Serological study of bovine leptospirosis in México. Revista Cubana de Medicina Tropical 54:24-27.

Panti-May, J. A., R. R. C. De Andrade, Y. Gurubel-González, E. PalomoArjona, L. SodÁ-Tamayo, J. Meza-Sulú, M. Ramírez-Sierra, E. Dumonteil, V. M. Vidal-Martínez, C. Machaín-Williams, D. DE Oliveira, M. G. Reis, M. A. Torres-Castro, M. R. Robles, S. F. Hernández-Betancourt, and F. COSTA. 2017. A survey of zoonotic pathogens carried by house mouse and black rat populations in Yucatan, México. Epidemiological Infections 145:2287-2295.

Sánchez-Montes, S., D. V. Espinosa-Martínez, C. A. Ríos-Muñoz, M. Berzunza-Cruz, and I. BeCKer. 2015. Leptospirosis in México: Epidemiology and Potential Distribution of Human Cases. PLoS One 10:e0133720.

Tamura, K., G. Stecher, D. Peterson, A. Filipski, and S. Kumar. 2013. Mega6: Molecular Evolutionary Genetics Analysis Version 6.0. Molecular Biology and Evolution 30:2725-2729.

Thibeaux, R., D. Girault, E. Bierque, M. E. Soupé-Gilbert, A. Rettinger, A. Douyère, M. Meyer, G. Iraola, M. Picardeau, and C. Goarant. 2018. Biodiversity of Environmental Leptospira: Improving Identification and Revisiting the Diagnosis. Frontiers in Microbiology 1:816.

Torres-Castro, M., L. Guillermo-Cordero, S. Hernández-Betancourt, E. Gutiérrez-Ruíz, P. Agudelo-Flórez, R. Peláez-Sánchez, J. F. ZavalaCastro, and F. I. Puerto. 2016. First histopathological study in kidneys of rodents naturally infected with Leptospira pathogenic species from Yucatan, México. Asian Pacific Journal of Tropical Medicine 9:145-147.
Torres-Castro, M., B. Cruz-Camargo, R. Medina-Pinto, B. ReyesHernández, C. Moguel-Lehmer, R. Medina, J. Ortiz-Esquivel, W. ArCilaFuentes, A. López-Ávila, H. No-Pech, A. Panti-May, I. Rodríguez-Vivas, And F. I. Puerto. 2018. Molecular detection of pathogenic Leptospira in synanthropic and wild rodents captured in Yucatán, México. Biomedica 38:51-58.

Vital-Brazil, J. M., I. T. Balassiano, F. S. Oliveira, A. D. Costa, L. Hillen, AND M. M. Pereira. 2010. Multiplex PCR-based detection of Leptospira in environmental water samples obtained from a slum settlement. Memorias do Instituto Oswaldo Cruz. 105:353-355.

Yager, R. H., W. S. Gochenour, A. D. Alexander, and P. W. Wetmore. 1953. Natural occurrence of Leptospira ballum in rural house mice and in an opossum. Proceedings of the Society for Experimental Biology and Medicine 84:589-590.

Zárate-Martínez, J. P., J. V. Rosete-Fernández, A. Ríos-Utrera, F. T. Barradas-Piña, and S. Olazarán-Jenkins. 2015. Prevalencia de Leptospirosis y su relación con la tasa de gestación en bovinos de la zona centro de Veracruz. Nova Scientia 7:202-217.

Associated editor: Jesús Fernández

Submitted: November 27, 2018; Reviewed: January 29, 2019;

Accepted:March 21, 2019; Published on line:May 12, 2019. 